\title{
Alteration of Air Transmittance of Plain Weft Knitted Fabrics for Different Parameters
}

\author{
Mohammad Mobarak Hossain ${ }^{1 *}$, Upama Nasrin $\mathrm{Haq}^{2}$, and Mohammad Mahmudur Rahman Khan ${ }^{1}$ \\ ${ }^{1}$ Assistant Professor, Department of Textile Engineering, Bangladesh University of Business and Tevchnology (BUBT), Mirpur-1216, Dhaka, \\ Bangladesh \\ ${ }^{2}$ Lecturer, Department of Textile Engineering, Bangladesh University of Textiles (BUTex), Tejgaon, Dhaka, Bangladesh
}

DOI: $10.36348 /$ sjet.2020.v05i11.009

| Received: 05.11.2020 | Accepted: 14.11.2020 | Published: 19.11.2020

*Corresponding author: Mohammad Mobarak Hossain

Abstract

Physical properties of fabric basically depend on fabric cover and porosity. Other fabric parameters that influence the air transmittance of a fabric are type of stitches used, type of yarn, linear density, twist factor in the yarn, stitch density, thickness, tightness factor and fractional cover of fabric and moisture content which has a circuitous effect on those parameters. Many researchers had already derived so many relationships among those parameters and the fabrics properties. But, air transmittance rate may influence other comfort properties of the fabric. Our investigation shows the relationship of different parameters which can alter the transmittance of air through the plain knitted fabric. Here, a little change in the structure can alter the air transmittance which has been represented graphically.

Keywords: Weft knitted fabric, air transmittance, fabric porosity, moisture content.

Copyright (C) 2020 The Author(s): This is an open-access article distributed under the terms of the Creative Commons Attribution 4.0 International License (CC BY-NC 4.0) which permits unrestricted use, distribution, and reproduction in any medium for non-commercial use provided the original author and source are credited.

\section{INTRODUCTION}

Air flow through textiles is mainly affected by the pore characteristics of fabrics which is a function of fabric geometry and depends on the yarn diameter, surface formation techniques, and stitch density [1,2]. Again three factors, namely cross-sectional area, depth of pore or thickness of the fabrics and number of pore per unit area or course and wales per unit area are related to pores in knitted fabrics [3].

The air exchange through clothing is highly influenced by the air transmittance of the fabric. The air permeability or transmittance of a fabric is the volume of air measured in cubic centimeters passed per second through $1 \mathrm{~cm}^{2}$ of the fabric at a pressure of $1 \mathrm{~cm}$ of water [4]. The air transmittance of fabric is closely linked to its structure. Many researchers have dealt with the possibility to predict the value of the permeability of woven fabrics based on their structural parameters [5]. But only few researchers have investigated the parameters linked with the air transmittance of the weft knitted fabrics. The aim of this paper is to investigate the alteration of air transmittance of plain weft knitted fabrics (single jersey, single lacoste, double pique) for different parameters. The parameters which were characterized for this investigation were porosity, stitch density, thickness, areal density, count, loop length and moisture content of the fabric. Fabric porosity depends on different fabric parameters and relaxation progression. A theoretical model was used to predict the porosity of a knitted structure in our research work [6]. Benltoufa's as well as Dias and Delkumburewatte's porosity equation and Karaguzel's pore radius equation measurement was applied for the prediction [7-9]. Though moisture content is not considered as a part of basic fabric it can influence the other, which properties of the structure ultimately can alter the air transmittance from the structure. But it is a complex issue to define the dominance of moisture content on the other properties [10]. Many researchers have investigated that thickness and areal density of fabric have direct relationship with the air transmittance of the structure $[11,12]$.

Physical and mechanical properties of textiles are determined primarily by their structure. Air permeability or transmittance as a physical property of fabric has a decisive influence on utilization of fabric for some technical applications (filters, parachutes, and sails) and clothing application as well [13].

In this investigation, we tried to find out the better relationship of different fabrics' parameters of plain weft knitted fabrics (single jersey, single lacoste 
Mobarak Hossain et al; Saudi J Eng Technol, Nov, 2020; 5(11): 451-456

and double pique) with the air transmittance to realize the reasons behind the change.

\section{EXPERIMENTAL MATERAILS AND METHOD \\ Materials}

For the investigation we have selected $100 \%$ cotton weft knitted fabric of single jersey, single lacoste and double pique which were manufactured from 'P. N .Composite' [14]. Specification of the single jersey was $(\mathrm{CPCm} \times \mathrm{WPCm}=21 \times 14,19 \times 11$, $20 \times 13)$; single lacoste was $(22 \times 9,35 \times 11,35 \times 11)$ and double pique was $(23 \times 8,38 \times 11,39 \times 10)$. Fibre identification test (Chemical test: $75 \%$ sulfuric acid solution) for the verification of the sample composition carried out in the chemistry lab of Bangladesh University of Business and Technology (BUBT, Dhaka, Bangladesh, 2016). These samples were immersed in a solution of water and wetting agents $5 \mathrm{~g} /$ litre at $50^{\circ} \mathrm{C}$ for 30 minutes and then dried on a flat surface in an unconditioned atmosphere for 24 hours.

\section{Machines and Instruments}

The areal density of the fabric was measured directly by the GSM cutter, stitch density was calculated from the $\mathrm{CPCm}$ and $\mathrm{WPCm}$. The $\mathrm{CPCm}$ and WPCm were counted by the counting glass. Loop length was calculated manually in thetesting lab of BUBT, Dhaka, Bangladesh. Thickness was calculated by the automatic thickness tester. The Benltoufa's formula $\left(1-\frac{\pi d^{2} l}{4 t C W}\right)$ and Dias and Delkumburewatte's formula $\left[\left(1-\frac{T l \times 10^{-5}}{W C t \rho}\right) \times 100 \%\right]$ were used to measure the porosity of the plain weft knitted fabric and Karaguzel's formula $\left[\sqrt{\frac{t \rho 10^{5}-S l T}{\rho 10^{5} \pi t s}}\right]$ was used to measure the pore radius of the plain weft knitted fabric [7-9]. Count was measured from the Beesley's Balance MAG - C 1101 directly. Moisture content was calculated by the formula using the sample weight and oven dry weight. For the weight electric balance, Model PAG 213 is used. To obtain the oven dried sample we use the drier machine of Model: MGH -030. To measure the air transmittance of the fabric we use MAG - C 2851 air permeability tester. All calculation is summarized in tables 1-2.

\section{METHODS}

Air permeability is usually measured as the volume of air that flows in unit time through unit area under unit pressure difference [15]. The air permeability of the treated sample was measured according to IS 11056 [16]. Areal density (GSM) was measured following the direction of ASTM D 3776 [17]. ASTM D1777 method was followed to measure the thickness of the samples [18]. Stitch length and linear density of the fabrics are determined by the TSE TS EN 14970 method [19]. WPCm (wales per centimeter) and $\mathrm{CPCm}$ (courses per centimeter) was calculated using the method of TSE - TS EN 14971 [20]. Moisture content of the sample was measured from the difference in total fabric weight and oven dry weight according to ASTM D 1909 [21].

\section{RESULTS AND DISCUSSION \\ Effects of porosity on air transmittance}

Porosity is the ratio of the total amount of void space in a material to the bulk volume occupied by the material [22]. The porosity of fabric influences the physical properties say-bulk density, moisture absorbency, mass transfer and thermal conductivity [8]. Three factors are related to the pores in knitted fabric such as cross-sectional area of each pore, depth of each pore or the thickness of the fabric and the number of pore per unit area or the number of courses and wales per unit area [23]. For the experimental investigation we have used three types of plain weft knitted fabrics: single jersey, single lacoste and double pique. We have characterized three samples of each type of fabric.

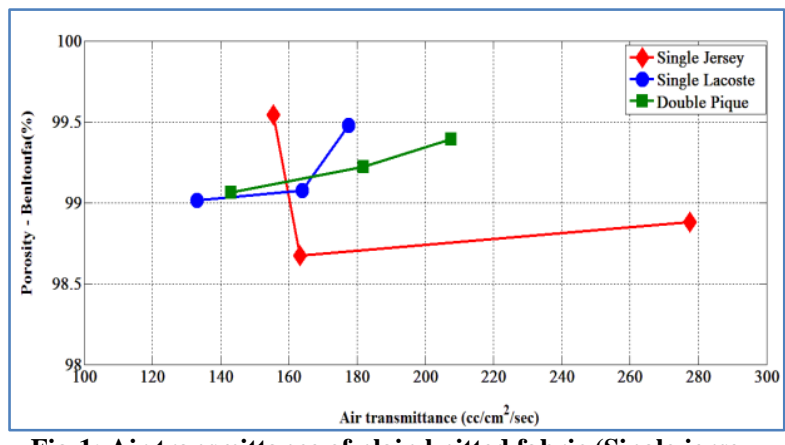

Fig-1: Air transmittance of plain knitted fabric (Single jersey, single lacoste and double pique) versus porosity \%( Benltoufa)

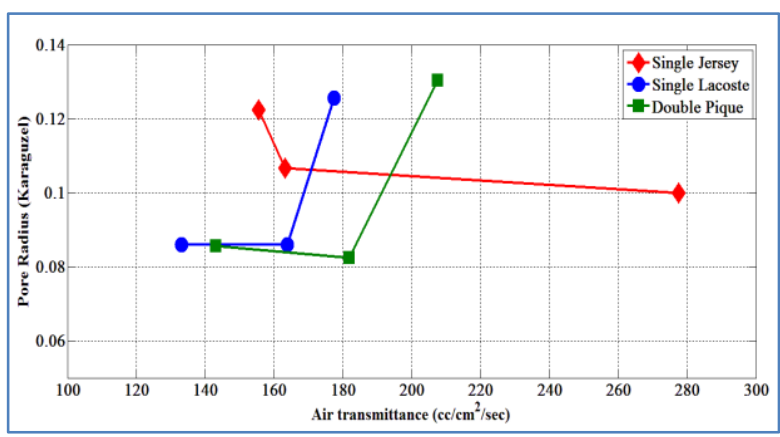

Fig-2: Air transmittance of plain knitted fabric (Single jersey, single lacoste and double pique) versus porosity \%( Karaguzel)

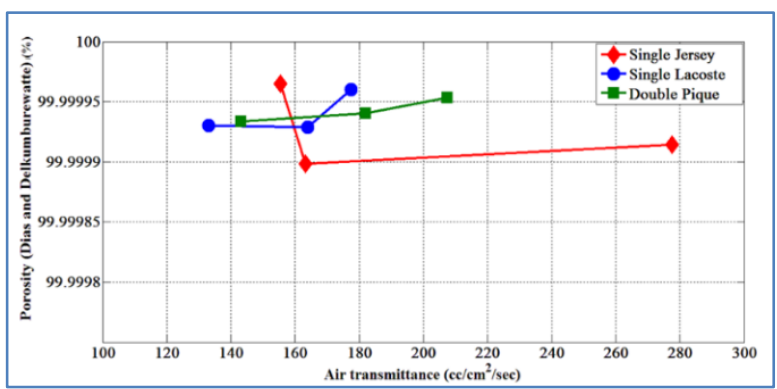

Fig-3: Air transmittance of plain knitted fabric (Single jersey, single lacoste and double pique) versus porosity \% (Dias and Delkumburewatte) 
After analyzing the data of the experiment we have found that a very small change in the percentage of the porosity of fabric makes a massive variation in the air transmittance $\left(\mathrm{cc} / \mathrm{cm}^{2} / \mathrm{sec}\right)$ of the fabric. It has been analyzed from the data (table-1) that if porosity of fabrics increased, air transmittance will also be increased. But, we have found some slight change in the porosity and pore radius calculation that affect the air transmittance in a little different angle. From our investigation we have found that the relationship between porosity percentage and air transmittance cannot be clearly defined for single jersey, whereas the double pique and single lacoste, have proportional relationship (fig.1-3). According to porosity measurement, more porous structure shows more air transmittance. Dias and Delkumburewatte and Karaguzel model shows diversion from Benltoufa porous model as they consider the fiber density and yarn count. More moisture content present in the samples may have changed the air transmittance here. So, we can conclude that whether the porosity or pore radius is increased or decreased, if other factor like moisture content cannot be controlled, air transmittance will be influenced (fig. 1-3).

\section{Effects of thickness on air transmittance}

The thickness of the fabric is dependent on its mass per unit area, the type of yarns used, the knitted structure and the finish [24]. Fabric thickness test is used to measure the thermal insulation, vapor transmission, stiffness, resilience, abrasion, stability etc. of the fabric [25]. After analyzing the data (table-2) it has been observed that the relationship between the thickness and air transmittance of single jersey is inversely proportional. Graphical presentation shows the result of the experiment (fig. 4). On the contrary, single lacoste and double pique indicate that other parameters influence air transmittance and is not directly related to the fabric thickness alone. It is just a single factor that will affect the air transmittance if and only if other parameters are completely unchanged. For less number of samples this relation may have been imprecise.

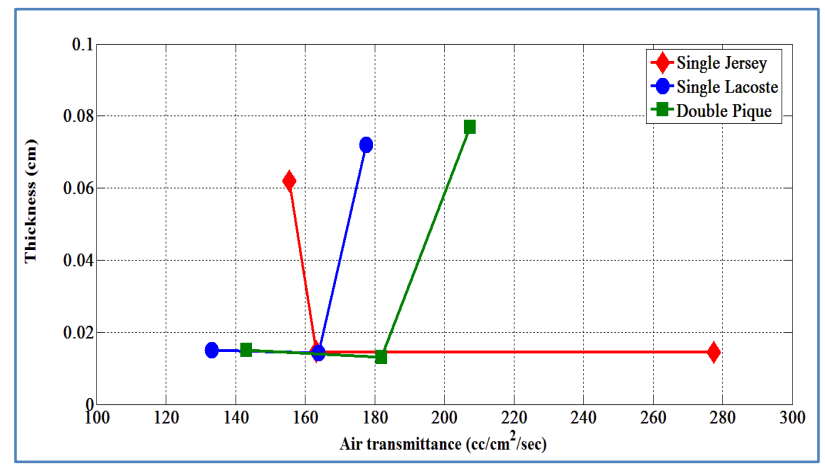

Fig-4: Effect of thickness on air transmittance

\section{Effects of areal density on air transmittance}

The air transmittance of fabric depends on the shape and value of the pores and the inter-thread channels, which are dependent on the structural parameters of the fabric [26]. The effects of knit structures on the air transmittance of fabric have been analyzed by Çeken [27] and Kavuşturan [28]. As areal density represents the combined changes of $\mathrm{CPCm}$, WPCm, stitch length, yarn fineness or coarseness and finishing treatments, we have found an inverse relationship between the air transmittance and areal density for both single lacoste and double pique from our experiment (table-2). But, due to the presence of excess of moisture content in one sample of single jersey this relation may have been slightly diversed (fig. 5).

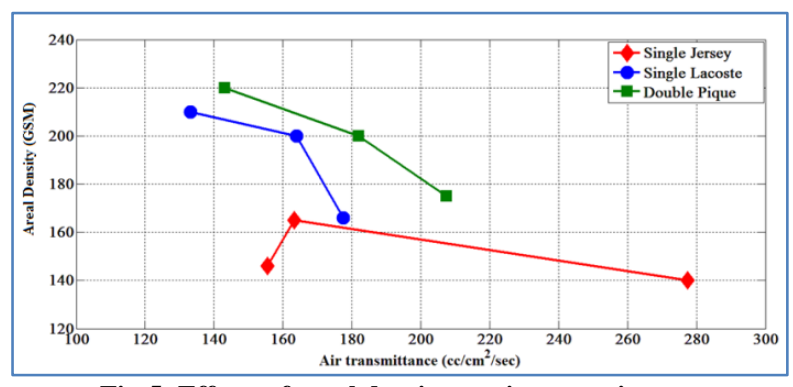

Fig-5: Effects of areal density on air transmittance

\section{Effects of stitch density $\left(\mathrm{cm}^{2}\right)$ on air transmittance}

Due to the three-dimensional curved shape of the loop, knitted structures are generally more porous and extensible than other textile structure [29]. Loose knitted structure is more permeable to air owing to their lower density [30]. Increase in stitch density reduces the porous area in the fabric construction. This proportional relationship is clearly found from the experiment for single jersey. But single lacoste and double pique have showed the effect of other parameters on air transmittance like moisture content and areal density as it does not represent the effect of other changes in the fabric construction (fig-6).

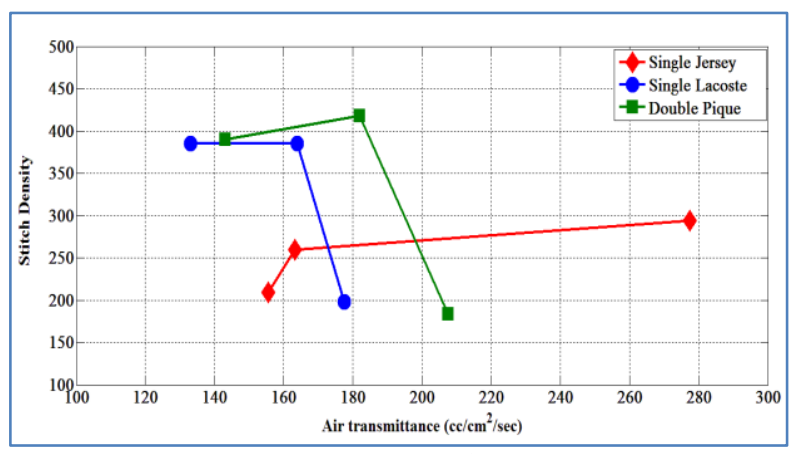

Fig-6: Effects of stitch density $\left(\mathrm{cm}^{2}\right)$ on air transmittance

\section{Effect of tightness factor and fractional cover on the air transmittance}

It is clearly found that tightness factor and fractional cover shows clear relation with the air permeability as they both represent the pore per unit area. Single lacoste and double pique shows inverse relation with air permeability except single jersey as it shows similar variation in relation with other 
parameters. So, it is clear that porosity, tightness factor and fractional cover all are related to the air permeability in the same way and found as substitution of each other in relation with air transmittance (table-2).

\section{Effects of moisture content (\%) on air transmittance}

Less number of samples does not give us an idea clearly about the effect of change of moisture content $(\%)$ on air transmittance. The result of our experiment made us confused to prepare a conclusion on this parameter. But if we analyze it as a whole, we will perceive that all models or relationship does not represent the moisture content as it is not a part of the basic fabric. But, moisture content has a clear effect that it may have blocked the porosity or pore radius of the fabric calculated by the various models. If moisture is entrapped in the pore radius highly, it shows less air transmittance which was not clearly revealed in this experiment. Further experiment needs to be done in this regard (table-5).

\section{CONCLUSIONS}

For decades, many researchers tried to represent many theories and models on fabric air transmittance for both knit and woven. Research results show that the transmittance of air could be varied on different parameters. We have considered different theories and models to summarize the relationship between air transmittance and fabric construction. Here, Moisture content to be the major factor that altered the theoretical relationship among those parameters. Decisive influence on the parameters which can alter the transmittance significantly for their minute alteration may have found. After analyzing the data it has been explored that porosity, pore radius, yarn diameter, CPCm, WPCm, fabric thickness, areal density, tightness factors and fractional cover have direct relationship with air transmittance. On the other hand, testing environment and fiber properties have great influence on the results and proved to be a major factor that had not been considered in this research. These factors should be considered in porosity or air transmittance model for plain knitted fabric geometry.

\section{ACKNOWLEDGEMENT}

Special thanks to P. N. Composite industry to allow us to produce the required fabric samples using their knitting machines with the help of some of our students from Textile Engineering Department, Bangladesh University of Business and Technology. Authors provided the full financial support in this study.

Table 1: Porosity Vs air Transmittance for different plain weft knitted fabrics

\begin{tabular}{|c|c|c|c|c|c|c|}
\hline $\begin{array}{c}\text { Type of } \\
\text { Fabrics }\end{array}$ & $\begin{array}{c}\text { Sl. } \\
\text { No. }\end{array}$ & $\begin{array}{c}\text { Porosity } \\
\text { (Benltoufa) }\end{array}$ & $\begin{array}{c}\text { Pore Radius } \\
\text { (Karaguzel) }\end{array}$ & $\begin{array}{c}\text { Porosity (Dias and } \\
\text { Delkumburewatte) }\end{array}$ & $\begin{array}{c}\text { Air transmittance } \\
\left(\mathrm{cc}_{\mathrm{cm}}^{2} / \mathrm{sec}\right)\end{array}$ & $\begin{array}{c}\text { Moisture } \\
\text { Content }(\%)\end{array}$ \\
\hline \multirow{3}{*}{ Single Jersey } & 1 & $98.8817 \%$ & 0.100126663 & $99.99991435 \%$ & 277.5 & 6.79 \\
\cline { 2 - 8 } & 2 & $98.6743 \%$ & 0.106777536 & $99.99989836 \%$ & 163.2 & 6.51 \\
\cline { 2 - 8 } & 3 & $99.5433 \%$ & 0.122463917 & $99.99996502 \%$ & 155.5 & 8.65 \\
\hline \multirow{3}{*}{$\begin{array}{c}\text { Single } \\
\text { Lacoste }\end{array}$} & 1 & $99.4781 \%$ & 0.125794759 & $99.99996003 \%$ & 177.5 & 8.7 \\
\cline { 2 - 8 } & 2 & $99.0732 \%$ & 0.086005421 & $99.99992894 \%$ & 163.9 & 6.48 \\
\hline \multirow{3}{*}{ Double Pique } & 3 & $99.0147 \%$ & 0.086091055 & $99.99993014 \%$ & 133.1 & 7.59 \\
\cline { 2 - 8 } & 1 & $99.3913 \%$ & 0.130485236 & $99.99995339 \%$ & 207.5 & 7.69 \\
\cline { 2 - 8 } & 3 & $99.221 \%$ & 0.082597614 & $99.99994042 \%$ & 181.9 & 7.27 \\
\hline
\end{tabular}

Table 2: Air transmittance Vs Tightness factor and Fractional Cover of different plain weft knitted fabrics.

\begin{tabular}{|c|c|c|c|c|c|c|c|c|}
\hline $\begin{array}{c}\text { Type of } \\
\text { Fabrics }\end{array}$ & $\begin{array}{c}\text { Sl. } \\
\text { No. }\end{array}$ & $\begin{array}{c}\text { Thickness } \\
(\mathrm{cm})\end{array}$ & $\begin{array}{c}\text { Areal } \\
\text { Density } \\
(\mathrm{GSM})\end{array}$ & $\begin{array}{c}\text { Stitch Density } \\
(\mathrm{CPCm} x \\
\text { WPCm })\end{array}$ & $\begin{array}{c}\text { Tightness } \\
\text { factor }\end{array}$ & $\begin{array}{c}\text { Fractional } \\
\text { Cover }\end{array}$ & $\begin{array}{c}\text { Air } \\
\text { Transmittance } \\
\left(\mathrm{cc} / \mathrm{cm}^{2} / \mathrm{s}\right)\end{array}$ & $\begin{array}{c}\text { Moisture } \\
\text { Content } \\
(\%)\end{array}$ \\
\hline \multirow{3}{*}{ Single Jersey } & 1 & 0.0144 & 140 & 294 & 1.58 & 0.38 & 277.5 & 6.79 \\
\cline { 2 - 10 } & 2 & 0.0147 & 165 & 260 & 1.64 & 0.35 & 163.2 & 6.51 \\
\cline { 2 - 10 } & 3 & 0.062 & 146 & 209 & 1.27 & 0.34 & 155.5 & 8.65 \\
\hline \multirow{3}{*}{ Single Lacoste } & 1 & 0.072 & 166 & 198 & 1.01 & 0.40 & 177.5 & 8.7 \\
\cline { 2 - 10 } & 2 & 0.0142 & 200 & 385 & 1.64 & 0.52 & 163.9 & 6.48 \\
\hline \multirow{3}{*}{ Double Pique } & 3 & 0.015 & 210 & 385 & 1.77 & 0.54 & 133.1 & 7.59 \\
\cline { 2 - 10 } & 2 & 0.077 & 175 & 184 & 0.87 & 0.44 & 207.5 & 7.69 \\
\cline { 2 - 10 } & 3 & 0.013 & 200 & 418 & 1.77 & 0.48 & 181.9 & 7.27 \\
\hline
\end{tabular}

\section{REFERENCES}

1. Çay, A., Vassiliadis, S., \& Rangoussi, M. (2005). On the use of image processing techniques for the estimation of the porosity of textile fabrics.
2. Çay, A., \& Tarakçioğlu, I. (2008). Relation between fabric porosity and vacuum extraction efficiency: Energy issues. Journal of the Textile Institute, 99(6), 499-504. 
3. Oğulata, R. T., \& Mavruz, S. (2010). Investigation of porosity and air permeability values of plain knitted fabrics.

4. Booth, J. E. (1970). Principles of textile testing.

5. Havlová, M. (2013). Air permeability and costructional parameters of woven fabrics. Fibres and Textiles in Eastern Europe.

6. Rahman, S., Smriti, S. A., \& Siddiqa, M. F. (2015). Investigate the relation among thickness, relative porosity and air permeability of different types of knitted fabrics. International Journal of Current Engineering and Technology, 5(6), 3907-3910.

7. Benltoufa, S., Fayala, F., Cheikhrouhou, M., \& Nasrallah, S. B. (2020). Porosity determination of jersey structure. Laboratoire d'Etudes des Systèmes Thermiques et Energétiques, ENIM, Monastir, 5019.

8. Dias, T., \& Delkumburewatte, G. B. (2008). Changing porosity of knitted structures by changing tightness. Fibers and Polymers, 9(1), 7679.

9. Karaguzel, B. (2004). North Carolina State University, Department of Textile Engineering, Chemistry and Science

10. Hamburger, W. (1954). Effect of yarn and fabric structure on air permeability (No. WADC-TR-5449). FABRIC RESEARCH LABS INC BOSTON MA.

11. Ogulata, R. T. (2006). Air permeability of woven fabrics. Journal of Textile and Apparel, Technology and management, 5(2), 1-10.

12. MEZARCIÖZ, S., MEZARCIÖZ, S., \& OĞULATA, R. T. (2014). Prediction of air permeability of knitted fabrics by means of computational fluid dynamics. Journal of Textile \& Apparel/Tekstil ve Konfeksiyon, 24(2).

13. Natarajan, K. (2003). Air permeability of elastomeric fabrics as a function of uniaxial tensile strain.

14. Composite P. N. (2016). [Online]. Available: (http://www.pncomposite.com).

15. ASTM. (1963). Paper and paperboard characteristics, nomenclature and significance of test, 3 ed., 61-62.

16. IS-11056. (1984). Method for determination of air permeability of fabrics, Delhi: Indian Standard.

17. Astm, D. (1990). Standard Test Methods for Mass Per Unit Area (Weight) of Fabric. ASTM.

18. ASTM D1777-96. (2015). Standard Test Method for Thickness of Textile Materials., West Conshohocken, PA, USA: American Society for testing and materials.

19. TSE - TS EN 14970, Textiles - knitted fabrics determination of stitch length and yarn linear density in weft knitted fabrics, Turkish Standards Institution, 2147483648, 2006.

20. TSE - TS EN 14971, Textiles - knitted fabrics determination of number of stitches per unit length and unit area, Turkish Standards Institution, 2147483648, 2006.
21. ASTM D 1909. (2004). Table of commercial moisture regains for textile fibers, vol. 7, West Conshohocken, PA, USA: Annual Book of ASTM Standards, ASTM International.

22. Elnashar, E. A. (2005). Volume porosity and permeability in double-layer woven fabrics. AUTEX Research Journal, 5(4), 207-217.

23. Oinuma, R. (1990). Effect of stitch length on some properties of cotton $1 \times \quad 1$ rib knitted fabrics. Journal of the Textile Machinery Society of Japan, 36(3), 91-95.

24. Taylor, M. (1990). Technology of Textile Properties, 3 ed., Forbes Publication, 191-192.

25. Booth, J. (1998). Principles of Textile Testing, CBS publishers \& distributors, 161-162.

26. Olsauskiene, A., \& Milasius, R. (2004). Integrated Fabric Firmness Factor as a Criterion of Air Permeability Designing. In Proc. 2nd International Textile Clothing \& Design Conference.

27. Çeken, F. (1997). An investigation about air permeability of wool/polyester and wool/acrylic knitted fabrics. Tekstil ve Konfeksiyon, 2, 111-115.

28. Kavuşturan, Y. (2002). The Effects of Some Knit Structures on the Fabric Properties in Acrylic Weft Knitted Outerwear Fabrics. Tekstil Maraton, 40-46. Kavuşturan, Y. (2002).

29. The Effects of Some Knit Structures on the Fabric Properties in Acrylic Weft Knitted Outerwear Fabrics. Tekstil Maraton, 40-46.

30. Pavko-Cuden, A., Hladnik, A., \& Sluga, F. (2013). Loop length of plain single weft knitted structure with elastane. Journal of Engineered Fibers and Fabrics, 8(2), 155892501300800214.

31. Nazir, A., Hussain, T., Ahmad, F., \& Faheem, S. (2014). Effect of knitting parameters on moisture management and air permeability of interlock fabrics. AUTEX research Journal, 14(1), 39-46.

32. Rahman, S., Smriti, S.A., \& Siddiqa, M.S.F. (2015). Investigate the Relation among Thickness, Relative Porosity and Air Permeability of different types of Knitted Fabrics, International Journal of Current Engineering and Technology, 5(6), $3907-$ 3910., 3907-3.

\section{BRIEF BIOGRAPHY}

Mohammad Mobarak Hossain has joined BUBT in the Department of Textile Engineering on June 7, 2014 as lecturer. After completing B.Sc. in Textile Engineering from Textile Engineering College, Chittagong, currently he is pursuing his M.Sc. in Textile Engineering from Bangladesh University of Textiles. He has more than one year of industrial experience in Production Quality Control and Industrial Engineering from Base Textile Mills Ltd. And Intimate Apparels Ltd. Respectively. His research interest includes lean techniques and production engineering in fabric technology.

Upama Nasrin Haq is serving as a Lecturer in the Department of Apparel Engineering under the 
faculty of Fashion Design and Apparel Engineering of Bangladesh University of Textiles. After completing B.Sc. in Textile Engineering with major in Apparel Engineering, she joined as Lecturer in Bangladesh University of Business \& Technology (BUBT) in February, 2014. Having a strong passion for research, she has carried out research work in various sections of Apparel and clothing specially washing technology and medical textiles with numerous research works. Mrs. Haq is a progressive reviewer in several peer reviewed journals. She has joined BUTex in October, 2017 with the drive of increasing her research knowledge.
Mohammad Mahmudur Rahman Khan graduated in Mechanical Engineering from Bangladesh University of Engineering and Technology (BUET) in 2011. He is currently continuing his post-graduate studies in the same institute. He is serving as an Assistant Professor in the Department of Textile Engineering, Bangladesh University of Business and Technology (BUBT). He is interested in fluid and thermal studies and wants to continue his research in these fields. 